ScIDice

\section{Evaluation of the Fit Accuracy of Removable Partial Denture Frameworks Fabricated Using Three Different Techniques: An In Vitro Study}

\section{International Journal of Dentistry and Oral Science (IJDOS) ISSN: $2377-8075$}

Research Article

Nariman Maraka ${ }^{1}$, Dr. Alaa'a Salloum², Dr. Mamdouh AlMohareb ${ }^{3}$, Safaa Shihabi* ${ }^{*}$

${ }^{1}$ Postgradguated Student (PhD Degree), Department of Removable Prosthodontics, Faculty of Dentistry, Damascus University, Syria.

${ }^{2}$ Professor in the Department of Removable Prosthodontics, Vice Dean For Scientific Affairs Faculty of Dentistry - Damascus University, Syria.

${ }^{3}$ Department of Oral Histology and Pathology, Faculty of Dentistry, Damascus University, Syria.

${ }^{4}$ DDS, MSc in Paediatric Dentistry, Damascus university, Syria.

\title{
Abstract
}

\begin{abstract}
Aim: To conduct a laboratory study to evaluate the fit accuracy of the structures of the removable partial denture frameworks fabricated by 3D printing method and the conventional method using gypsum models.

Materials and Methods: Fifteen patients with partial tooth loss of a maxillary Kennedy class I. They were divided into three groups: in the first group, the removable partial denture frameworks were fabricated from chromium-cobalt using CS casting technique; in the second group, the removable partial denture frameworks were fabricated from chromium-cobalt using selective laser melting (SLM) technique; and in the third group, the removable partial denture frameworks were fabricated from poly ether ether ketone (PEEK) using Milling technique. The fabricated frameworks were injected with polyvinyl siloxane (PVS) and were pressed to produce gypsum models, and then the rubber laminas were weighted.

Results: The results of the one-way ANOVA test showed that there were statistically significant differences in the average weight of the rubber laminas in the three groups, where $\mathrm{P}<0.05$. The largest gap was in the group of SLM frameworks, followed by the group of CS frameworks, and the lowest was in the group of Milling frameworks which achieved the best fit accuracy to the gypsum models.

Conclusions: The structures of the removable partial denture frameworks fabricated from PEEK using Milling technique achieved the best fit accuracy on the gypsum models compared with the structures of Cr-Co fabricated using another two different methods, where the accuracy was affected by the fabricating technique used.
\end{abstract}

Keywords: Fit Accuracy; Removable Partial Denture Framework; Selective Laser Melting; Casting; Milling.

\section{Introduction}

Removable partial denture frameworks are considered the best treatment in many clinical cases, especially in the case of loss of bony and tissue support $[1,2]$. Removable partial denture frameworks were used clinically in the mid-nineteenth century. It is likely that removable partial denture frameworks will remain a treatment option compared to the more expensive alternatives [3].

To date, Cr-Co alloys are considered one of the most popular metal alloys used in the fabrication of removable partial denture frameworks. This is due to their high hardness, excellent resistance to corrosion and oxidation, lower price compared to gold alloys, and their thermal conductivity $[4,5]$. However, despite the advantages of Cr-Co alloy, it has some defects, such as inflammatory reactions to the oral tissues, the existence of a metallic taste, and the failure to meet the patient's aesthetic requirements in cases where the retainers of the clasps appear $[6,7]$.

In order to satisfy patients, new materials have been developed using new techniques that outperform the conventional method of fabricating removable partial denture frameworks which take a long time and great effort to complete [8, 9]. In addition, it requires many laboratory procedures which are subjected to human error [10]. Thereby, here was the task of orientation and development in the digital field, where the technology computer-aided design/computer-aided manufacturing (CAD-CAM) appeared. The main developments of CAD-CAM systems in dentistry were in

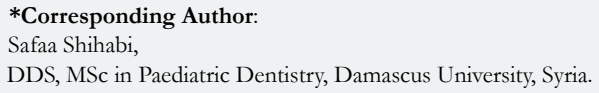

Citation: Nariman Maraka, Dr. Alaa'a Salloum, Dr. Mamdouh AlMohareb, Safaa Shihabi. Evaluation of the Fit Accuracy of Removable Partial Denture Frameworks Fabricated Using Three Different Techniques: An In Vitro Study. Int J Dentistry Oral Sci. 2021;8(10):4881-4886. doi: http://dx.doi.org/10.19070/2377-8075-21000987

Copyright: Safaa Shihabi ${ }^{\circ}$ 2021. This is an open-access article distributed under the terms of the Creative Commons Attribution License, which permits unrestricted use, distribution and reproduction in any medium, provided the original author and source are credited. 
the early eighties, and this technology was used in crowns, bridges, dental implants, maxillofacial prostheses, and in the fabrication of removable partial denture frameworks [11, 12]. Recently, additive manufacturing (AM) technology was introduced. It includes Selective Laser Sintering (SLS) technique for non-metallic materials such as ceramics and polymers in addition to the Selective Laser Melting (SLM) technique for metal mixtures (powder) $[13,14]$ in which layers are created using a high-energy laser beam to melt the metal powder and fuse it to form a three-dimensional object $[15,16]$.

The medical literature has also reported numerous cases of inaccurate fit of the different components of removable partial denture frameworks fabricated from Cr-Co alloys, which can range from minor which requiring minor in-clinic adjustments, to large enough which requiring the fabrication of a new metal frameworks. This unfit reflects the dimensional change that occurs in the different stages of making metallic frameworks [17]. The question of searching for a material with ideal properties for fabricating the removable partial denture frameworks remains a matter of concern to researchers.

Therefore, many thermoplastic materials have been introduced in clinical practice and the poly ether ether ketone (PEEK) appeared, which was first marketed in 1980 [18]. Because of the properties of PEEK which include chemical and physiological stability, bio-acceptance, wear resistance, and resistance to radiation damage and stability at high temperatures, PEEK may be an alternative to Co-Cr alloys. Furthermore, its distinctive properties make it an interesting material for use in dentistry with potential using it according to CAD-CAM technique. The PEEK has been modified with $20 \%$ ceramic addition to be suitable for fabricating the bases of the removable partial denture frameworks [19, 20]. Digital technologies have revolutionized the production of removable partial denture frameworks through Milling technique for new polymeric materials, poly ether ether ketone (PEEK), or AM technique represented by SLS or SLM for metal structures to save time through: rapid fabrication; quality of the product structure; shortness of work stages using three-dimensional scanners inside or outside the mouth; and the development of the design programs used. The digital removable partial denture frameworks have obtained patient satisfaction in terms of frameworks stability and permanence according to recent clinical trials [21].

All CAD-CAM systems consist of three components:

1. Digitalization Tool/ Scanner.

2. Design software (Software).

3. Production Technique [22].

\section{Materials and Methods}

The research includes fifteen patientswho come to the Department of Removable Prosthodontics at the Faculty of Dentistry at Damascus University. They suffer from upper partial loss of teeth of Kennedy class I, as similar as possible within the conditions of inclusion and exclusion. They are distributed into three groups equally, where each group includes 5 Patients:

1. In the first group: a framework of Cr-Co alloys was fabricated using the CS casting method for each patient.
2. In the second group: a framework of Cr-Co alloys was fabricated using the SLM method for each patient.

3. In the third group: a framework of PEEK was fabricated using Milling method for each patient.

Designing a useful and comfortable removable partial denture framework requires carefulness in diagnosis, planning, implementation, and maintenance [1].

The conventional method used to fabricate the removable partial framework of Cr-Co alloys using the CS casting was as follows:

The preliminary impressions were taken using alginate (Hygedent Inc., China) and plastic stamps (Solo, Syria). Then the stamps were casted with dental gypsum (Ruthenium, Dental Manufacturing, Italy) to get the preliminary cast. Then The preliminary cast was studied and plotted with a diagram (Ney Gold, The J.M. Company, USA). The essential patient's mouth preparations were made to receive the partial framework according to the selected design. The final impression was taken with alginate Hygedent. The final master cast was obtained by casting the gypsum model. The metal frameworks design was made using the master gypsum cast. The master cast was configured and prepared for duplicating to obtain a master cast-resistant. The components of the partial framework were set (major connectors - minor connectors - clasps - direct retainers - indirect retainers) [1, 23]. The master cast-resistant was coated using wax (Tenatex Type 1 Soft, Kemdent, UK), and then the crucible was placed in the furnace (Realloy-Grmany) so that the wax evaporated, and thus the metal framework fabricated from Cr-Co was obtained.

The method used to fabricate the removable partial framework of Cr-Co alloys using the SLM method was as follows:

The same steps in the conventional methodwere followed to get the final master gypsum cast. The steps of the SLM fabricating process identified by Gibson et al. [24]:

1. Computer-aided designing (CAD): production of a 3D model using the design program (Exocad), and scanning of the final gypsum model was conducted using the scanner (CS. Ultra Pro). 2. Transmitting the design obtained in the first step to the STL format.

3. Transferring to the Selective Laser Fusion Machine (Sisma Mysint) and modifying the STL file. The STL file was copied to the computer that controlled the $3 \mathrm{D}$ printer, to determine the printing size and construction direction of the frameworks.

4. Preparing the machine and packing the Cr-Co powder (Scheftner-Germany) needed for the printing process.

5. Building (start printing): in this step the machine built the frameworks automatically.

6. Removal: removing the printed partial framework from the machine with following the safety precautions to avoid injury.

7. Post-treatment: this included wiping away some of the powder residue and cleaning the printed framework to remove the backings; therefore, the object should be handled with care.

Thus, the removable partial framework was fabricated using SLM method.

The method used to fabricate the removable partial framework from PEEK using Milling method was as follows: 
It follows the same stages used in fabricating the Cr-Co framework with SLM technique, where in the third stage the printing file was transferred to the 3D printer Roland-Dw510, and the printer sculpted the PEEK block (China ${ }^{\text {TM}}$-PEEK) that was installed in the place designated for it, and thus the removable partial denture framework was fabricated from PEEK using Milling method [2]. The method of studying the accuracy of major connector:

A similar method to Rantanen et al 1986 [25] and Aljammal 2013 [26] was used to check the fit accuracy of the major connector for upper removable partial denture frameworks at the stage where the final model was obtained.

The middle line of the palatine dome is drawn on the master model, and a flexible numbered plastic piece with $1 \mathrm{~cm}$ wide and 2 $\mathrm{cm}$ long is placed at a distance of $5 \mathrm{~mm}$ from the back edge of the framework, so that it applies to the palatine dome, and its center line applies to the center line of the palatine dome. Then six points were drawn by a pencil: a point at each corner of the plastic piece, and a middle point on each side at a distance of $1 \mathrm{~cm}$ from the points at the corners of the piece as in the Figure (1-A). After that, six fosses corresponding to the six points were drilled with a depth of approximately $0.5 \mathrm{~mm}$ using a metal bur (HM 1SQL, Bego, Germany) with a diameter of $0.8 \mathrm{~mm}$ as in Figure (1-B). Then the metal framework was fabricated from $\mathrm{Cr}$-Co alloys, with a palatine lamina of about $0.5 \mathrm{~mm}$ thickness. This thickness was used by many researchers to make the palatine lamina of the CrCo alloys [27-29]. The manufacturer's instructions were followed during the processes of coating, casting and finishing.

Then the final gypsum model was scanned to design the frameworks of the frameworks fabricated from PEEK using Milling technique and Cr-Co frameworks fabricated using SLM technique after drilling fosses on the models. The models were then immersed in water for 10 minutes, and dried with napkins. After that, a quantity of polyvinylsiloxane (Hydrorise Extra Light Body, Zhermack, Italy) was injected on the inner surface of the frameworks using the injector (Ivoclar). Each one was placed on its own model, making sure that the spurs and clasps were correctly in place. Then a pressing with the thumb was done in the center of the palatal dome until the soft rubber was completely hardened, as shown in Figure (1-C-D-E). Then the framework was taken from the model.

A piece of polyvinyl siloxane was cut using a sharp scalpel (Maped) around the impressions of the six fosses. Then a precise cut using a scalpel and a metal ruler was made to the piece containing the six fosses depending on the six fosses where the cutting line was tangent to the outer boundaries of the impressions of the fosses. The cutting rubber lamina was kept in a closed container, and then weighed using a sensitive electronic balance (Sartorius, AG Gottingen, Germany) as shown in Figure (1-F).

\section{Results}

The one-way ANOVA test was conducted to study the significance of the differences in the average weights of rubber laminas between the group of frameworks fabricated from Cr-Co alloys using SLM technique, the group of those fabricated from $\mathrm{Cr}$-Co alloys using CS technique, and the group of those fabricated from PEEK using Milling technique for the samples of fit accuracy study. The results were as in Table 1:

The table shows the results of one-way ANOVA, from which we conclude that there are statistically significant differences in the average weight of the rubber lamina in the studied sample of the fit accuracy of the removable partial framework, where the value of $\mathrm{f}$ is 40.418 with a probability value of 0.000 (less than 0.05 ), and it is statistically significant. In addition,the table shows that the largest gap is in the group of frameworks fabricated from Cr-Co alloys using SLM technique, followed by frameworks fabricated from $\mathrm{Cr}$-Co alloys using CS technique, then the group of frameworks fabricated from PEEK using Milling technique. Table (2) shows the results of the Tukey dimensional comparison test:

It is clear from Table (2) that the reason for the statistically significant differences in the weight of the rubber lamina in the sam-

Figure 1.

\begin{tabular}{|c|c|c|}
\hline 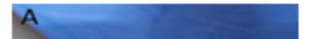 & & C \\
\hline $\begin{array}{l}\text { (A) Determination of the drilling } \\
\text { location on the gypsum } \\
\text { model }\end{array}$ & $\begin{array}{l}\text { (B) The gypsum model after } \\
\text { drilling the fosses with a bur }\end{array}$ & $\begin{array}{l}\text { (C) Chromium-cobalt structure } \\
\text { fabricated using CS } \\
\text { technique on the gypsum } \\
\text { model after injection of PVS }\end{array}$ \\
\hline $\begin{array}{l}\text { (D) Chromim-cobalt framervork } \\
\text { fabricated using SLM techrique } \\
\text { on the gypsum model after } \\
\text { injection of PVS }\end{array}$ & $\begin{array}{l}\text { (E) Polyether ether ketone } \\
\text { (PEEK) framework } \\
\text { fabricated using Milling } \\
\text { technique on gypsum model } \\
\text { after injection of PVS }\end{array}$ & $\begin{array}{l}\text { (F) Rubber lamina weight on } \\
\text { sensitive electronic scale }\end{array}$ \\
\hline
\end{tabular}


Figure 2. The difference in the weight of the rubber lamina between the three groups in the sample of the fit accuracy study.

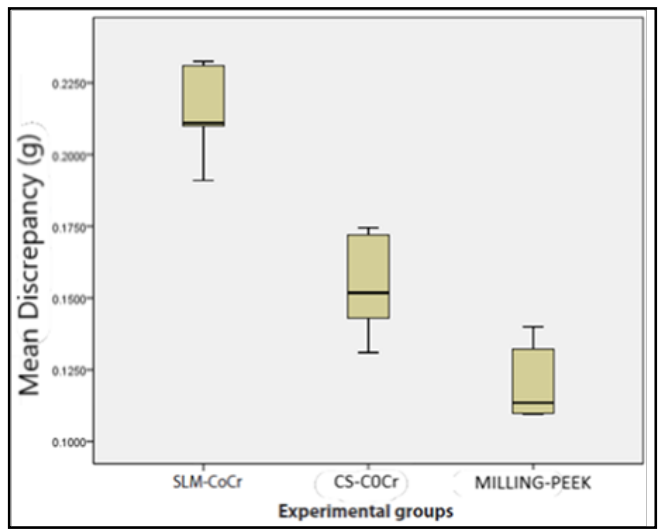

Table 1. Shows the results of the one-way ANOVA test, the average, and the standard deviation of the weight of the rubber lamina (in grams) in the samples of fit accuracy study according to the type of framework used.

\begin{tabular}{|c|c|c|c|c|c|c|}
\hline \multirow{2}{*}{$\begin{array}{l}\text { Studied vari- } \\
\text { able }\end{array}$} & Type of & Average & \multirow{2}{*}{$\begin{array}{l}\text { Standard } \\
\text { deviation }\end{array}$} & \multirow{2}{*}{ f } & \multirow{2}{*}{$\mathrm{p}$ value } & \multirow{2}{*}{$\begin{array}{l}\text { Statistical signifi- } \\
\text { cance }\end{array}$} \\
\hline & framework used & (gram) & & & & \\
\hline \multirow{3}{*}{$\begin{array}{l}\text { weight of } \\
\text { rubber lamina } \\
\quad \text { (gram) }\end{array}$} & $\begin{array}{l}\text { Framework fabricated from Cr-Co } \\
\text { alloys using SLM }\end{array}$ & 0.215 & 0.017 & \multirow{3}{*}{40.418} & \multirow{3}{*}{0} & \multirow{3}{*}{ statistically significant } \\
\hline & $\begin{array}{c}\text { Framework fabricated from } \mathrm{Cr}-\mathrm{Co} \\
\text { alloys using CS }\end{array}$ & 0.154 & 0.019 & & & \\
\hline & $\begin{array}{c}\text { Framework fabricated from PEEK } \\
\text { using Milling }\end{array}$ & 0.121 & 0.014 & & & \\
\hline
\end{tabular}

Table 2. Tukey's Test Results.

\begin{tabular}{|c|c|c|c|c|}
\hline Studied variable & $\begin{array}{l}\text { Tech- } \\
\text { nique }\end{array}$ & $\begin{array}{c}\text { Difference between } \\
\text { the averages }\end{array}$ & $\mathrm{p}$ value & Statistical significance \\
\hline \multirow{3}{*}{$\begin{array}{l}\text { weight of rubber } \\
\text { lamina (gram) }\end{array}$} & $\begin{array}{c}\text { SLM \& } \\
\text { CS }\end{array}$ & 0.061 & 0 & statistically significant \\
\hline & $\begin{array}{l}\text { SLM \& } \\
\text { Milling }\end{array}$ & 0.094 & 0 & statistically significant \\
\hline & $\begin{array}{l}\text { CS \& } \\
\text { Milling }\end{array}$ & 0.033 & 0.021 & statistically significant \\
\hline
\end{tabular}

ple of the fit accuracy study is due to the difference between the group of Cr-Co structures fabricated by SLM technique and the group of PEEK framework fabricated using Milling technique with a significant difference of 0.09410 , and a significant difference of 0.06064 for the group $\mathrm{Cr}$-Co frameworks fabricated using CS technique, where the P value was 0.000 (less than 0.05). While the significant difference between the group of $\mathrm{Cr}$-Co structures fabricated by CS technique and the group of PEEK frameworks fabricated using Milling technique is 0.03346 , where the $P$ value was 0.021 (less than 0.05).

According to the above-mentioned study, the research hypothesis is accepted, which states that there are statistically significant differences in the average weight of the rubber lamina (in grams) on the gypsum model between the group of frameworks fabricated from Cr-Co alloys using SLM technique, the group of frameworks fabricated from Cr-Co alloys using CS technique, and the group of frameworks fabricated from PEEK using Milling technique in the sample of the accuracy study. The best accuracy is in the PEEK group using Milling technique, followed by the $\mathrm{Cr}-\mathrm{Co}$ group using CS technique, followed by the Cr-Co group using
SLM technique as in Figure (2):

\section{Discussion}

In this study, Kennedy Class I upper removable partial denture frameworks were fabricated using three different methods: Casting method, Selective Laser Melting method, and Milling method. Then the fit accuracy of the frameworks applied to the gypsum models was evaluated through injecting PVS between the framework and the gypsum model.

The results of the study shows that there is a clear difference in the fit accuracy between the three groups, and thus the null hypothesis is rejected. The largest gaps were in the $\mathrm{Cr}$-Co frameworks using SLM technique, where the average weight of PVS was 0.215100 , followed by the gaps in the structures of Cr-Co frameworks fabricated using CS technique, where the average weight of PVS was 0.154460, while the least gaps were found in the group of frameworks fabricated from PEEK using Milling technique, where the average weight of PVS was 0.121000 , and thus this technique achieved the best fit to gypsum models. 
The explanation for the large gaps in Cr-Co frameworks fabricated using SLM technique is due to the presence of a large area for the palatine lamina (the basal lamina), as there are large fluctuations in temperature in a short time, and this causes high thermal stresses that in turn cause residual pressures and lead to shrinkage of the palatine lamina and this shrinkage affects the fit accuracy of fabricated frameworks [30].

There are also other factors that affect the accuracy: the laser beam diameter; the speed of scanning; the thickness of the powder; and the angle of construction [31]. Thereby, it is necessary to conduct more research to obtain the best values for these factors because of the importance of their impact on accuracy. In addition, the material used in taking the impression and casting the gypsum model and scanning by the scanner plays an important role in accuracy.

As for the frameworks fabricated using CS casting method although there is a human error because the manufacturing process is done manually in addition to the effect of metal expansion and contraction, the removable partial frameworks fabricated from PEEK using Milling technique achieved the least gap as it is done in one step and does not require the trimming and finishing operations that are needed in the previous two methods.

Although there is a statistically significant difference in the average weight of PVS between the three groups, it may have no clinical significance because the oral mucosa and gingival tissue have a degree of flexibility that compensates for the gap [31].

This study agreed with the study of Chen et al. in 2019 [31] where it was found that the removable partial denture frameworks of Kennedy class I fabricated using CS casting technique have fewer gaps than those fabricated using SLM technique, and this was explained by the shrinkage of the palatine lamina accompanying the SLM process. While it was found in Kennedy class III, the gap in SLM technique was less than that in CS. On the other hand, Ye H et al. 2017 [32] also compared the fit accuracy of the removable partial denture frameworks fabricated using SLM technique with those fabricated using CS casting technique for different Kennedy classes by PVS. It was found that the gaps in the frameworks fabricated using CS casting technique are less than those of the frameworks fabricated using the SLM technique. Furthermore, our study agreed with Wang 2018 [33], where it was found that the removable partial frameworks fabricated from PEEK material using Milling technique had a better fit accuracy than the frameworks of Cr-Co fabricated using CS technique.

\section{Conclusions}

Based on the results of this study, the following conclusions were drawn:

1- The fit accuracy of the removable partial frameworks fabricated from PEEK using Milling technique was better compared of the removable partial frameworks fabricated from Co-Cr using SLM and CS techniques.

2- The removable partial denture frameworks fabricated using SLM technique were the least fit.
3- Cr-Co frameworks fabricated using SLM and CS techniques were less accurate compared to frameworks fabricated from PEEK using Milling technique. This was due to the deformation (shrinkage) of the metal accompanying the fabricated process.

\section{References}

[1]. Benso B, Kovalik AC, Jorge JH, Campanha NH. Failures in the rehabilitation treatment with removable partial dentures. Acta Odontol. Scand. 2013 Nov 1;71(6):1351-5.

[2]. Bohnenkamp DM. Removable partial dentures: clinical concepts. Dent. Clin. N. Am. 2014 Jan 1;58(1):69-89.

[3]. Preshaw PM, Walls AW, Jakubovics NS, Moynihan PJ, Jepson NJ, Loewy Z. Association of removable partial denture use with oral and systemic health. J. Dent. 2011 Nov 1;39(11):711-9.

[4]. Schwitalla A, Müller WD. PEEK dental implants: a review of the literature. J Oral Implantol. 2013 Dec;39(6):743-9.

[5]. Becker CM, Kaiser DA, Goldfogel MH. Evolution of removable partial denture design. J Prosthodont. 1994 Sep;3(3):158-66.

[6]. Arda T, Arikan A. An in vitro comparison of retentive force and deformation of acetal resin and cobalt-chromium clasps. J Prosthet Dent. 2005 Sep;94(3):267-74.Pubmed PMID: 16126079.

[7]. Thomas P, Bandl WD, Maier S, Summer B, Przybilla B. Hypersensitivity to titanium osteosynthesis with impaired fracture healing, eczema, and T-cell hyperresponsiveness in vitro: case report and review of the literature. Contact Dermatitis. 2006 Oct;55(4):199-202.Pubmed PMID: 16958916.

[8]. Jones JD, Garcia LT. Removable partial dentures: a clinician's guide. John Wiley \& Sons; 2009 Aug 7.

[9]. Carlsson GE, Omar R. Trends in prosthodontics. Med Princ Pract. 2006;15(3):167-79.

[10]. Bajunaid SO, Altwaim B, Alhassan M, Alammari R. The Fit Accuracy of Removable Partial Denture Metal Frameworks Using Conventional and 3D Printed Techniques: An In Vitro Study. J Contemp Dent Pract. 2019 Apr 1;20(4):476-481. Pubmed PMID: 31308280.

[11]. Williams RJ, Bibb R, Eggbeer D, Collis J. Use of CAD/CAM technology to fabricate a removable partial denture framework. J Prosthet Dent. 2006 Aug 1;96(2):96-9.

[12]. Bilgin MS, Baytaroğlu EN, Erdem A, Dilber E. A review of computer-aided design/computer-aided manufacture techniques for removable denture fabrication. Eur. J. Dent. 2016 Apr;10(02):286-91.

[13]. Van Noort R. The future of dental devices is digital. Dental materials. 2012 Jan 1;28(1):3-12.

[14]. Kruth JP, Mercelis P, Van Vaerenbergh J, Froyen L, Rombouts M. Binding mechanisms in selective laser sintering and selective laser melting. Rapid Prototyp. J. 2005 Feb 1;11(1):26-36.

[15]. Sun J, Zhang FQ. The application of rapid prototyping in prosthodontics.J Prosthodont. 2012 Dec;21(8):641-4.

[16]. Yager S, Ma J, Ozcan H, Kilinc HI, Elwany AH, Karaman I. Mechanical properties and microstructure of removable partial denture clasps manufactured using selective laser melting. Addit. Manuf. 2015 Oct 1;8:117-23.

[17]. Gowri V, Patil NP, Nadiger RK, Guttal SS. Effect of anchorage on the accuracy of fit in removable partial denture framework. J Prosthodont. 2010 Jul;19(5):387-90.Pubmed PMID: 20456025.

[18]. Moore DJ, Freeman MA, Revell PA, Bradley GW, Tuke M. Can a total knee replacement prosthesis be made entirely of polymers?. J. Arthroplasty. 1998 Jun 1;13(4):388-95.

[19]. Kurtz SM, Devine JN. PEEK biomaterials in trauma, orthopedic, and spinal implants. Biomaterials. 2007 Nov 1;28(32):4845-69.

[20]. Zoidis P, Papathanasiou I, Polyzois G. The Use of a Modified Poly-EtherEther-Ketone (PEEK) as an Alternative Framework Material for Removable Dental Prostheses. A Clinical Report. J Prosthodont. 2016 Oct;25(7):580584.PubmedPMID: 26216668

[21]. Tamimi F, Almufleh B, Caron E, Alageel O. Digital removable partial dentures. Clin. Dent. Rev. 2020 Dec;4(1):1-12.

[22]. Albuha Al-Mussawi RM, Farid F. Computer-Based Technologies in Dentistry: Types and Applications. J Dent (Tehran). 2016 Jun;13(3):215-222. Pubmed PMID: 28392819.

[23]. Viswambaran M, Sundaram RK. Effect of storage time and framework design on the accuracy of maxillary cobalt-chromium cast removable partial dentures. Contemp Clin Dent. 2015 Oct-Dec;6(4):471-6.Pubmed PMID: 26681850.

[24]. Gibson I, Rosen D, Stucker B. Additive Manufacturing Technologies: Rapid Prototyping to Direct Digital Manufacturing. Media. 200;54.

[25]. Rantanen T, Eerikäinen E. Accuracy of the palatal plate of removable partial 
dentures, and influence of laboratory handling of the investment on the accuracy. Dent Mater. 1986 Feb;2(1):28-31.Pubmed PMID: 3519331.

[26]. Aljammal AM. In-vivo and in-vitro comparative study between removable partial dentures fabricated by using titanium alloys and removable partial dentures fabricated by using cobalt-chromium alloys. Damascus University. 2013:77-90

[27]. Ali M, Nairn RI, Sherriff M, Waters NE. The distortion of cast cobalt-chromium alloy partial denture frameworks fitted to a working cast. J Prosthet Dent . 1997 Oct 1;78(4):419-24.

[28]. Onodera S, Hosoi T, Morito M, Miwa E, Okikura Y, Tsuchida F, et al. [Clinical evaluation of the metal-based denture using superplastic titanium alloy for upper edentulous patients]. Nihon Hotetsu Shika Gakkai Zasshi. 1989 Dec;33(6):1381-7.Pubmed PMID: 2489779.

[29]. Wakabayashi N, Ai M. A short-term clinical follow-up study of superplastic titanium alloy for major connectors of removable partial dentures. J Prosthet Dent. 1997 Jun;77(6):583-7.Pubmed PMID: 9185050.
[30]. Kruth JP, Deckers J, Yasa E, Wauthlé R. Assessing and comparing influencing factors of residual stresses in selective laser melting using a novel analysis method. Proceedings of the institution of mechanical engineers, Part $B: j$. eng. manuf. 2012 Jun;226(6):980-91.

[31]. Chen H, Li H, Zhao Y, Zhang X, Wang Y, Lyu P. Adaptation of removable partial denture frameworks fabricated by selective laser melting. J Prosthet Dent. 2019 Sep 1;122(3):316-24.

[32]. Ye H, Ning J, Li M, Niu L, Yang J, Sun Y, et al. Preliminary Clinical Application of Removable Partial Denture Frameworks Fabricated Using Computer-Aided Design and Rapid Prototyping Techniques. Int J Prosthodont. 2017 Jul/Aug;30(4):348-353.Pubmed PMID: 28697204.

[33]. Ye H, Li X, Wang G, Kang J, Liu Y, Sun Y, et al. A Novel Computer-Aided Design/Computer-Assisted Manufacture Method for One-Piece Removable Partial Denture and Evaluation of Fit. Int J Prosthodont. $2018 \mathrm{Mar} /$ Apr;31(2):149-151.Pubmed PMID: 29448267. 